Ömer Halisdemir Üniversitesi İktisadi ve İdari Bilimler Fakültesi Dergisi

Yll: Ocak 2019 Cilt-Sayl: 12(1) ss: 83-92

Academic Review of Economics and Administrative Sciences

Year: January 2019 Vol-Issue: 12(1) pp: 83-92

http://dergipark.gov.tr/ohuiibf/

\title{
Explanatory Power Of Price Shocks In Food Security Equation Of Net Food Buyers In Nigeria
}

Felix O. ACHOJA

Daniel C. OKEKE ${ }^{2}$

\begin{abstract}
In a developing country such as Nigeria, fluctuation in macroeconomic factors can bring about food price shocks and food insecurity. It is important to investigate whether food price shocks have impacted the food security status of net food buying households. This study specifically examines the effect of food price shocks on the food security status of net food buying households in Nigeria. Secondary data were elicited from Central Bank of Nigeria and National Bureau of Statistics for the 1995-2016 years period. In analyzing the collected data, descriptive statistics (mean and percentage), coefficient of variation and regression model were used. The result revealed that all macroeconomic factors except exchange rate have a positive and significant relationship with food price shock. The result also indicated a $64.35 \%$ variation in food price shock with a variation of $38.07 \%$ in consumption expenditure (food security status) over the time period. On account of this, minimum consumption expenditure was over N1,304 compared to the World Bank consumption expenditure per person. Hence revealing that net buying households have extremely high cost of living and low welfare status (food security status). On the basis of this findings. It is recommended that the government should implement policies and regulations that will control and stabilize those macroeconomic factors that can agitate increases in food prices and cause food price shocks. This study had filled the knowledge gap by providing information on the degree to which food price shocks can affect the food security status of net food buying households in Nigeria.
\end{abstract}
Key Words
: Food security, Price shocks, Consumption expenditure, Net food buyers.
Jel Classification
: $Q 11$.

\footnotetext{
${ }^{1}$ Dr., Department of Agricultural Economics and Extension, Delta State University, Asaba Campus, Nigeria, lixmero40@yahoo.com, ORCID: http://orcid.org/0000-0002-9705-4923

2 Dr., Nwafor Orizu College of Education, Nsugbe, Nigeria, olisdon@yahoo.com, ORCID: http://orcid.org/0000-0002-9402-0656
} 


\section{INTRODUCTION}

Food and Agriculture Organization (FAO)world estimates shows that high food prices have increased world hunger (FAO, 2009a, FAO 2009b). Information abound in the media and public debate fora about affected individuals, families and communities.

Food crisis is a necessity of life thathas been identified as one of the most disturbing issues in world economy. It suffices therefore to say that all that governance requires is the formulation of policies and programs that would articulate a road map towards primarily achieving food security for the citizen of any country (Andohol, 2012) including Nigeria.

The combined effect of food price and income shocks arising from the global food and financial crises have been claimed to be the likely causes of the sharp increase in hunger and poverty in low income countries (FAO, 2009a, 2009b) including Nigeria.

The validity of the above clams and their core points of argument have not been sufficiently analyzed by empirical investigation in Nigeria. Even where there are similar studies they are deficient on the bases of wrong methodology without emphasis on the links between food price shocks and household welfare of net buying households. Emphasis in this study is placed on the net buying households as not all households are buyers. Some are producers and the effect of food price shock varies depending on the household pinpoint.

It is therefore pertinent to conduct this study to test the link or otherwise between food price shocks and net buying household welfare (food security) especially in Nigeria. Furthermore, a research on the nexus between food price, shocks and food insecurity is warranted (Swinnew and Squicciarine, 2012).

Arising from national food market survey data in Nigeria, it has been observed that food price shocks has undergone unsteady pattern, it has also been observed that there is linkage between unsteady food price and food insecurity in countries such as Afghan and Bangladesh. Special mapping of food data revealed high variation in the level of food insecurity over space and time.

Investigating the trends of food price shocks and the corresponding food insecurity of net buying house-holds in Nigeria deserves thorough investigation. The essence is to accentuate the pattern of food price instability in the long run and in the short run. It study be noted that unsteady food price is capable of disorganizing household budget and national economic plan in Nigeria.

The degree of food price shocks ought to be estimated quantitatively for the purpose of prediction. FAO, report shows that $3 / 4$ of rural household heads and $97 \%$ of households in urban areas are net buyers of food(FAO, 2014). Net food buyers require information on food price shocks because they are the worst-hit as it tends to negatively affect their welfare.

Furthermore, net food buyers tend to shift consumption pattern and adopt other economic adjustment mechanisms in the advent of food price shocks and food insecurity, these adjustment mechanisms by households in Nigeria deserves critical investigation.

Food crisis is one of the most disturbing social and economic problems confronting both developed and developing nations such as Nigeria. While the developed nations presses the relevant resources to deal with food crisis, developing nations including Nigeria, are still battling with food crisis in the face of climate change, social and economic realities.

D'souza and Jolliffe (2012) reported the relationship between levels of conflict and declining food security status of households in Afghan. Furthermore, studies on the impact of food price shocks on household food security are rare in literature.

The study conducted by Dimova and Gbakou (2013) on the impact of food price shocks on household welfare in Cote d'Ivoire was unable to capture the long run welfare impacts of food price shocks because the study was done at the time when the food price shock was still ongoing. 
In Nigeria an analysis of the degree of influence of food price shocks, on household food security dynamics remained unclear. Thus knowledge gaps obviously exist with respect to;

$i$. Long term and short run distortion impact of food price shocks on net buying household's food security status and

ii. The extent to which further food price shock may aggravate the already worse food security of net food buyers in Nigeria.

On the basis of the identified knowledge gaps, the present study was conducted. It is important to investigate the degree of food price shocks (food price variation) so as to ascertain the corresponding variation in food security states of net buying household in the Nigeria. Furthermore, it is important to examine this issue so as to understand who ultimately gains and who loses from high food prices, especially among the poor, and why. This knowledge will enable appropriate policies and programs to target those most in need.

The finding of this study is of immense benefit to welfare policy makers government, donor agencies and net buying household in Nigeria.

Some pertinent questions that this research was structured to answer were;

What is the trend of food price shocks in Nigeria (1995-2016)? Is there a significant food price shocks in Nigeria (1995-2016)? Is there significant relationship between food price shocks and household food security status? What are the determinants of food price shocks?

The broad objective of this study is to examine the impact of food price shocks on food security status among households in Nigeria.

The specific objectives of the study were to:

i. examine the trends of food price shocks and food security status in Nigeria (1985-2016).

ii. $\quad$ ascertain the degree of food price shocks in Nigeria (1995-2016).

iii. determine food security status of net food buying households in Nigeria (1995-2016).

iv. evaluate the relationship between food price shocks and food security status of households.

v. Examine the macroeconomic determinants of food prices shocks.

\section{RESEARCH METHODOLOGY}

\section{I.I. The Study Area}

The empiricalinvestigation was done in Nigeria. This location was chosen for the study due to the presence of price shocks on food security status among household in Nigeria.

Nigeria occupies between longitudes 20 and 150 East and Latitudes 40 to 140 North. It occupies 924,000 sq. kilometers. It is demarcated into 7 ecological zones which are characterized by swamp vegetation in the South and Sahel savanna in the North. The distinct ecological conditions determine the different agricultural practices throughout the country. The type of agriculture practiced ranges from arable crops, permanentcrops to pastoralism. 


\section{I.II. Data Collection Techniques}

The study utilized time series data obtained from Central Bank of Nigeria (CBN) statistical bulletin. The secondary data covered food price in Nigeria for the past 22 years. It included data on consumption expenditure per person (capital) for the period.

\section{I.III. Techniques for Data Analysis}

a. Trend analysis of food price shock: This objective was achieved using descriptive statistical tools such as mean and percentages as well as tables.

b. Macroeconomics determinants of food shocks: This objective was achieved using multiple regression model

Model specification on macroeconomic determinants of food price shocks.

$$
F P S=\beta 0+\beta 1 E X R+\beta 2 I R+\beta 3 G D P+\beta 4 M S+e i
$$
equation 1

Where

FPS $=$ food price shock, EXR $=$ Exchange rate, $I R=$ Inflation rate, GDP $=$ Gross Domestic Product, MS = Money Supply

$\beta 0-\beta 4=$ coefficient or estimate $\mathrm{ei}=$ stochastic error term

c. Degree of food price shocks in Nigeria 1995-2016: This objective was achieved using a linear regression model.

Model specification for the degree of food price shock in Nigeria 1995-2016.

$$
F P S=\beta 0+\beta 1 Y R+e i
$$
equation 2

Where

FPS $=$ Food price shock, $\mathrm{YR}=$ years, $\beta 0-\beta 1=$ coefficient or estimates, $\mathrm{ei}=$ stochastic error term

d. Food security status of net food buying household in Nigeria: This objective was analyzed using coefficient of variation of historical food price.

The model of specification for this objective is given as;

$$
\begin{aligned}
& C V(F P)=\frac{S D F P S}{X F P S 1} \quad x \quad 100 \ldots \ldots \ldots \ldots \ldots \ldots \ldots \text { equation } 3 \\
& C V(C E X)=\frac{S D C E X x}{X C E X 1} \quad 100 \quad \ldots \ldots \ldots \ldots \ldots . . . . . . . \text { Equation } 4
\end{aligned}
$$

Where

$\mathrm{SD}=$ Standard deviation, $\mathrm{X}=$ mean

FPS $=$ food price shock and CEX $=$ consumption expenditure (food security status) 
e. Explanatory power of food price shocks on food security status of households: This objective was achieved using linear regression model. Model specification showing the causal relationship between food price shocks and food security status

$$
C E X=\beta 0+\beta 1 F P S+e i \ldots \ldots \ldots \ldots \ldots \ldots \ldots \text { equation } 5
$$

Where;

$\mathrm{CEX}=$ food price shocks, $\beta 0-\beta 1=$ coefficient or estimate, $\mathrm{ei}=$ stochastic error term.

\section{RESULT AND DISCUSSION}

\section{II.I. The Trend of Food Price Shocks in Nigeria 1995-2016}

Table 1. Food price index statistics

\begin{tabular}{|l|l|l|l|l|l|}
\hline Years & $\begin{array}{l}\text { Food price } \\
\text { index }\end{array}$ & $\begin{array}{l}\text { Exchange Rate } \\
\text { (Naira) }\end{array}$ & $\begin{array}{l}\text { Inflation } \\
\text { Rate }\end{array}$ & $\begin{array}{l}\text { GDP (Billion } \\
\text { Naira) }\end{array}$ & $\begin{array}{l}\text { M1 (Money supply } \\
\text { Billion Naira) }\end{array}$ \\
\hline 1995 & 29.5 & 21.88 & 7.5 & 2316730 & 23370 \\
\hline 1996 & 31.8 & 21.88 & 13 & 2316730 & 26277.6 \\
\hline 1997 & 33.6 & 21.88 & 4.5 & 2617550 & 27380.8 \\
\hline 1998 & 37.1 & 21.89 & 7.2 & 2765379 & 33667.4 \\
\hline 1999 & 29.1 & 92.69 & 57 & 3371366 & 45446.9 \\
\hline 2000 & 31.4 & 102.1 & 2.8 & 4727522 & 47055 \\
\hline 2001 & 40.4 & 111.94 & 29.3 & 5374339 & 68662.5 \\
\hline 2002 & 45.4 & 121.97 & 8.5 & 6232244 & 87499.8 \\
\hline 2003 & 46.4 & 129.35 & 10 & 6061700 & 129085.5 \\
\hline 2004 & 56.7 & 133.5 & 6.6 & 11411067 & 198479.2 \\
\hline 2005 & 65.3 & 132.14 & 6.9 & 15610882 & 266944.9 \\
\hline 2006 & 68.8 & 128.65 & 18.9 & 18564595 & 318763.5 \\
\hline 2007 & 73.9 & 131.43 & 12.9 & 23280715 & 370333.5 \\
\hline 2008 & 88.5 & 130.74 & 14 & 63425154 & 429731.3 \\
\hline 2009 & 99.6 & 130.27 & 15 & 67220242 & 525637.8 \\
\hline 2010 & 105.5 & 98.113 & 17.9 & 71897722 & 699733.7 \\
\hline 2011 & 118.1 & 119.71 & 8.2 & 77552539 & 1036080 \\
\hline 2012 & 134.9 & 116.03 & 13.7 & 82053605 & 1315869 \\
\hline 2013 & 150.4 & 98.94 & 11.7 & 90895429 & 1599495 \\
\hline 2014 & 165.8 & 152.21 & 23.2 & 116781237 & 2815846 \\
\hline 2015 & 180.6 & 169.32 & 24.5 & 121450845 & 4027902 \\
\hline 2016 & 197.4 & 373.01 & 32.3 & 138340980 & 5349253 \\
\hline & & & & \\
\hline
\end{tabular}

Sources: CBN Statistical Bulletin 2016 and NBS 2016.

The Table 1 shows the food price index statistics from the year 1995 to 2016 . The food price index maintained a steady rise over the years with a moderate change in the food price index from 29.5 in 1995 to 65.3 in 2005 which is about $54.8 \%$ change in the span of 10 years. In 2006, it increased from 68.8 to 118.1 in 2011 which is a growth rate of about $41.7 \%$. This increase was so alarming compared to the earlier moderate increase between 1995-2005. The increase in food price index continued rapidly that as at 2016 it was at 197.4. Within this period, an increase in other economic factors such as inflation rate, money supply, exchange rate and money supply was also recorded. 


\section{II.II. Macroeconomics Determinants of Food Price Shocks}

Table 2. Determinants of food price shocks

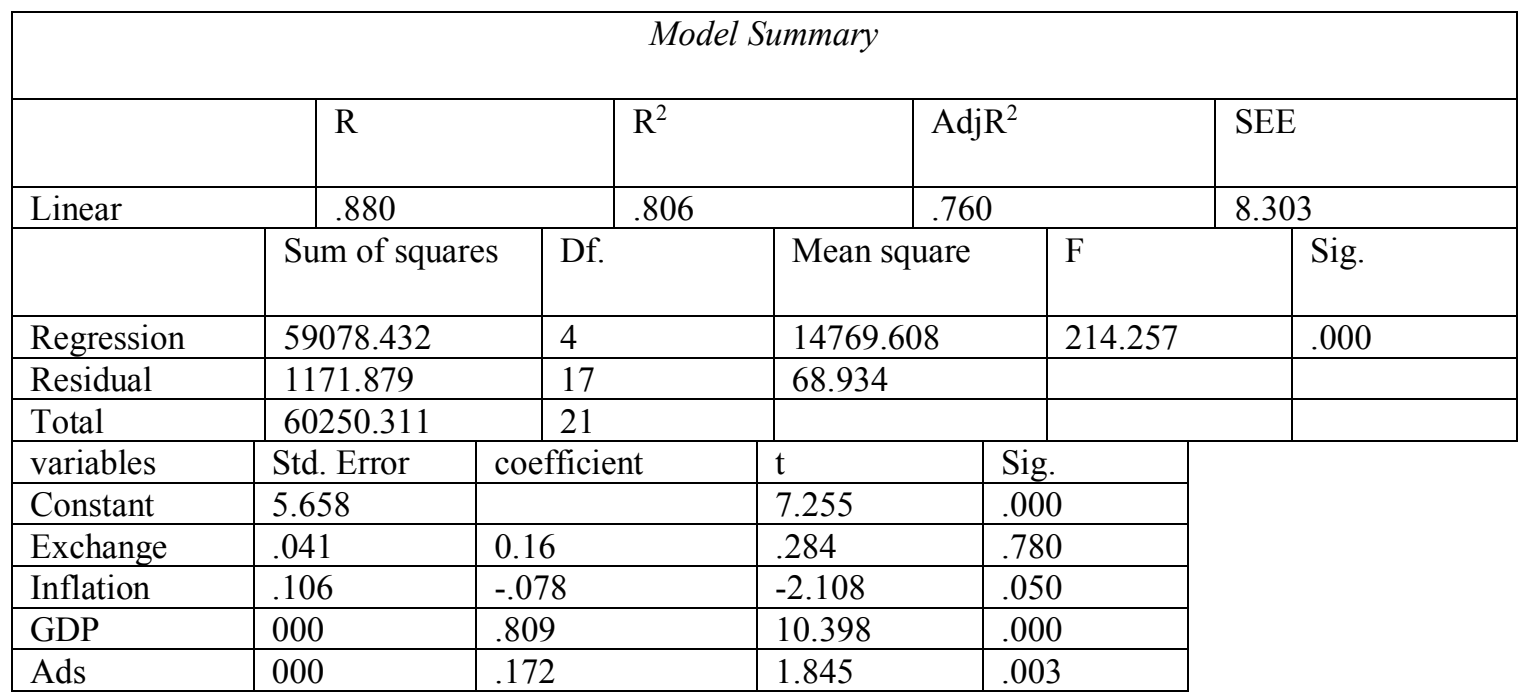

Dependent variable: Food price

Independent Variables: Exchange rate, inflation rate, GDP and Money supply

$* 1 \%$ level of significance

$* * 5 \%$ level of significance

Table 2 presents the results showing the determinants of food price shocks. The R2 value of $0.806(80.6 \%)$ indicates that macroeconomic factors is responsible for food price shocks by $80.6 \%$. T-statistics was then used to test the significance of the parameter coefficients. The test indicated that three out of the four macroeconomic factors was significant $(\mathrm{p}<0.05)$.

Inflation Rate: The result in Table 2 showed that inflation rate has a negative but significant relationship with food price $(0.880)(\mathrm{F}(4,17)=214.257: \mathrm{p}<0.05)$. The beta weight $(\mathrm{B}=-0.078: \mathrm{p}<0.05)$ implies that inflation rate is a negative predictor of food price and that a $1 \%$ increase in inflation rate will decrease food price shock by $0.078 \%$.

The equation of this model is therefore given as

$$
\begin{aligned}
& F P S=41.047+0.016 E X R-0.078 I N R+0.809 G D P+0.172 M S+e i \\
& (7.255)(0.284) \quad(-2.108)^{* *}(10.398)^{*} \quad(1.845)^{* *}
\end{aligned}
$$

GDP: The result of this study indicated that Gross Domestic Product has a positive and significant relationship with food price $(0.880)(\mathrm{F}(4,17)=214.25: \mathrm{p}<0.05)$. based on the beta weight $(\mathrm{B}=0.809: \mathrm{p}<0.00)$ it was deduced that a $1 \%$ increase in the GDP translates to a $0.81 \%$ increase in food price shock.

Money Supply: The result in table 4.2 indicated that money supply has a positive and significant relationship with food price $(0.880)(\mathrm{F}(4,17)=214.25$ : $\mathrm{p}<0.05)$. based on the beta weight $(\mathrm{B} 0.172: \mathrm{p}<0.003)$ it is deduced that $1 \%$ increase in money supply will increase food price shock by $0.17 \%$.

Exchange Rate: Although exchange rate shows no significance, a positive relationship is observed. The beta weight sign $(B=0.016: \mathrm{p}>0.05)$ indicates that with $1 \%$ increase in exchange rate, a proportionate increase of $0.02 \%$ in food price shock is observed. 
II.III. Degrees of Food Price Shocks and Variation in Food Security (Consumption Expenditure) of Net Food Buying Households in Nigeria 1995-2016

Table 3. The degree of food price shocks between 1995-2016.

\begin{tabular}{|c|c|c|c|c|c|c|c|c|}
\hline \multicolumn{9}{|c|}{ Model Summary } \\
\hline & \multicolumn{2}{|l|}{$\mathbf{R}$} & & $\mathbf{R}^{2}$ & \multicolumn{3}{|c|}{ Adj. $\mathbf{R}^{2}$} & SEE \\
\hline Linear & \multicolumn{2}{|l|}{.949} & & .901 & \multicolumn{3}{|c|}{.896} & 17.24104 \\
\hline & \multicolumn{2}{|c|}{ Sum of squares } & Df. & \multicolumn{3}{|c|}{ Mean square } & $\mathbf{F}$ & Sig. \\
\hline Regression & \multicolumn{2}{|l|}{54305.240} & 1 & \multicolumn{3}{|c|}{54305.240} & 182.690 & .000 \\
\hline Residual & \multicolumn{2}{|l|}{5945.071} & 20 & \multicolumn{3}{|c|}{297.254} & & \\
\hline Total & \multicolumn{2}{|l|}{60250.311} & 21 & & & & & \\
\hline variables & Std. Error & \multicolumn{2}{|c|}{ coefficient } & \multicolumn{2}{|c|}{$\mathrm{t}$} & \multicolumn{2}{|l|}{ Sig. } & \\
\hline Constant & 7.610 & \multicolumn{2}{|c|}{-6.822} & \multicolumn{2}{|l|}{-.897} & & \\
\hline Time & .579 & \multicolumn{2}{|c|}{.949} & 13.510 & & \multicolumn{2}{|l|}{$\begin{array}{l}.381 \\
000\end{array}$} & \\
\hline
\end{tabular}

Dependent variable: Food price

Independent Variables: Time (Yrs)

$* 1 \%$ level of significance

From the above Table 3, the degree of food price shocks is increased as food prices levies over the years. The R2 (coefficient) implies that there has been a $90.1 \%$ variation in food prices over the years (1995-2016). T-statistics showed that there is a very significant and positive relationship (0.949) $\mathrm{F}(1,20)=182.690: \mathrm{p}<0.05)$ between food price and time period (year). The beta weight as seen in the table above $(B=0.949: \mathrm{p}<0.00)$ indicates that a unit change in year leads to a $0.95 \%$ increase in food price. This finding is supported by the CBN statistical bulletin (2016) in which food price index increased geometrically as the years progressed.

$$
F P S=\frac{-6.822 .}{(-0.897)}+\frac{0.9494}{(13.516)}+e i
$$

\section{II.IV. Food Security Status of Net Food Buying Household in Nigeria}

Table 4. Descriptive statistics of operational variables

\begin{tabular}{|l|l|l|l|l|l|}
\hline & $\mathrm{N}$ & Minimum & Maximum & Mean & Std. deviation \\
\hline Food price & 22 & 29.10 & 197.40 & 83.23 & 53.56 \\
\hline Exchange & 22 & 21.88 & 373.01 & 116.34 & 71.91 \\
\hline Inflation & 22 & 6.60 & 72.80 & 22.78 & 18.73 \\
\hline GDP & 22 & 2316729.60 & 13834098.00 & 42466753.21 & .45 \\
\hline Di & 22 & 23370.00 & 5349253.30 & 883705.16 & 1418937.99 \\
\hline Consumption by household & 22 & 2104.00 & 6121.00 & 3883.86 & 1478.48 \\
\hline Valid no (list wise) & 22 & \multicolumn{3}{|l}{} \\
\hline
\end{tabular}

This result shows that the mean food price is $\mathrm{N} 83.24$ while the mean consumption expenditure is N3883.8636. Using coefficient of variation, the following results were derived.

$$
\begin{array}{lcrrr}
\text { C.V of food price }= & \frac{53.5636297}{83.236364} & x & \frac{100}{1} & =64.35 \% \\
\text { CV of consumer expenditure } & =\frac{1,478.48}{3,883.86} & x & \frac{100}{1} & =38.07 \%
\end{array}
$$


This result implies that the variation in food price was $64.35 \%$ while variation in consumer expenditure was $38.07 \%$. This indicates that food price change is higher than the consumer expenditure.As a result of this food security can be said to be low.

From Table 4, it is shown that the minimum consumption expenditure if net food buying households was N2,104 while the maximum consumption expenditure of net food buying households was N6,121. In accordance to the world bank regulation, the poverty line is currently 2 per day person which equates to about $\mathrm{N} 800$ at the current exchange rate of dollar to naira. This implies that an average Nigerian food buying household is spending about N1,304 extra on an average on feeding and consumption and as a result of spending more on feeding, high cost of living is incurred which translates to low households' welfare.

\section{II.V. Explanatory Power of Food Price on Consumption Expenditure (Food Security Status) of Net Food Buying Households}

Table 5. Multiple regression result showing the causal relationship between food price shocks and food security status of Net food Buyers

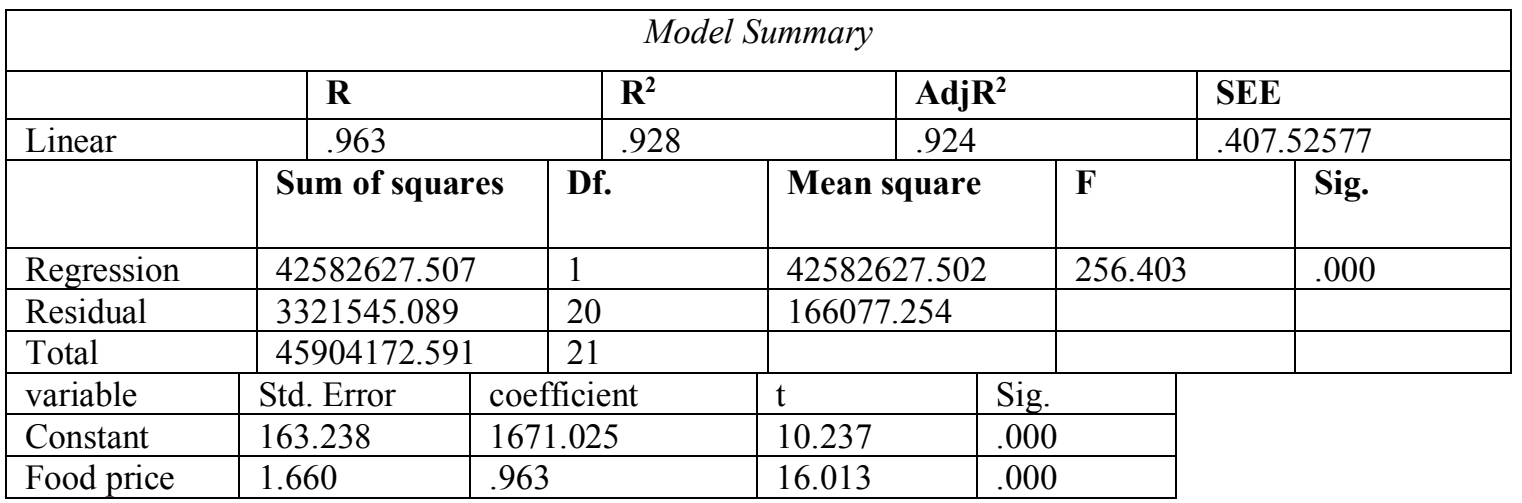

Dependent variable: Consumption expenditure

Independent Variables: Food price

$1 \%$ level of significance.

$\mathrm{HO}_{1}$ : $\quad$ There is no significant relationship between food price shock and consumption expenditure of net food buying households in Nigeria.

From the result in Table 5, it is seen that there is a significant and positive relationship between consumption expenditure (food security status) and food price shock $(0.063) \mathrm{F}(1,20)=$ 256.403:p<0.05). The R2 value of 0.923 implies that $92.8 \%$ of changes in household consumption expenditure is accounted for by change in food price.

T-statistics shows that consumption has a positive and significant relationship with food price shock and based on this result the null hypothesis is rejected and the alternative is accepted. The beta weigh $(\mathrm{B}=0.963: \mathrm{p}<0.00)$ as seen in food price will lead to a $0.96 \%$ increase in consumption expenditure.

The model for this relationship is hence given as

$\mathrm{CS}=1671.025+0.963 \mathrm{FP}+\mathrm{ei}$

$\mathrm{t}=(10.239)^{*}(16.013)^{*}$

This result implies that price shocks has strong explanatory power on the food security status of net food buying households both in the short run and long run in Nigeria. This finding supports earlier assertion of Arndt et al.(2012), that real food consumption expenditure seems to have largely 
followed the price dynamics with the potential for affecting the nutritional status of under-five children.

\section{CONCLUSION AND RECOMMENDATIONS}

This study investigated food price shock and effect on food security status of net buying households in Nigeria. The continued and rapid increase in food prices over the years has led to a shock that affected the nation's food security status especially the net food buying households. The elimination of food price shocks in the nation will be achievable by its ability to control macroeconomic factors through policies and regulations. Following the fluctuating trends in food price shock, it was revealed in this study, that food price shock accounted for $92.8 \%$ of the variation in the consumption expenditure of net buying households' in the nation and that based on the world bank poverty line net buying households incur N1,304 more in consumption. This in turn reduces their welfare status and makes cost of living extremely high.

The food security status of net food buying households in Nigeria can be modified and made stable through implementation of polices and regulations to control the macroeconomic factors that influence food price shocks.

On thebasis of the research findings it was recommended that:

i) Food security programmes by the government should be directed at net food buying households in Nigeria.

ii) Policies and regulations should be made to control and stabilize those macroeconomic factors that can agitate indiscriminate increases in food prices.

iii) Adjustment mechanisms such as taxation and subsidies should be employed by the government to respond to food price shocks.

iv) Nigeria food security reserves may be considered one of the major components of national strategies for preventing and managing for crisis. The low level of food stocks is often a cause of price hikes.

v) Supporting national programs and initiatives for food security, and harmonizing national food and agricultural policies where necessary.

\section{REFERENCES}

Arndt, C., R. Benfica, N. Maximiano, A.M.D. Nucifora and J.T. Thurlow. (2012). "Higher Fuel and Food Prices: Impacts and Responses for Mozambique." Agricultural Economics 39(1): 497511.

Arndt Channing, M. Azhar Hussain, Vincenzo Salvucci, Lars Peter Østerdal (2016). "Effects of food price shocks on child malnutrition: The Mozambican experience 2008/2009", Economics \& Human Biology,

CBN (2011). Monetary Policy, CBN, Abuja, Nigeria. Available at: http://www.cenbank.org/MonetaryPolicy/policy.asp.

CBN (2012). 2012 Statistical Bulletin: Domestic Production, Consumption and Prices, CBN, Abuja, Nigeria. Available at: http://cenbank.org/documents/Statbulletin.asp.

CBN (2013). Quarterly Statistical Bulletin, 2 (1) March 2013- Tables. CBN, Abuja, Nigeria. Available at: http://cenbank.org/documents/Statbulletin.asp.

CBN (Central Bank of Nigeria). (2006). Statistical Bulletin 16(2), CBN, Abuja, Nigeria. 
D’Souza, Anna, Dean Jolliffe. (2013) "Conflict, food price shocks, and food insecurity: The experience of Afghan households", Food Policy,

FAO. (2009a). Food and Agricultural Organization of United Nations (FAO), Rome). Available at: http://faostat.fao.org/site/368/DesktopDefault.aspx?PageID=368\#ancor.

FAO. (2009b). Food Balance Sheet - Nigeria, FAOSTAT (Online Statistical database of the Food and Agricultural Organization of United Nations (FAO), Rome). Available at: http://faostat.fao.org/site/368/DesktopDefault.aspx?PageID=368\#ancor.

FAO. (2014). Food Balance Sheet - Nigeria, FAOSTAT (Online Statistical database of the Food and Agricultural Organization of United Nations (FAO), Rome). Available at: http://faostat.fao.org/site/368/DesktopDefault.aspx?PageID=368\#ancor.

NBS (2012). The Nigeria Poverty Profile (2010) Report. Press Briefing by the Statistician General of the Federation / Chief Executive Officer, National Bureau of Statistics (NBS), held at NBS Headquarter on 13/02/2012, Abuja, Nigeria. Available at: http://www.proshareng.com/reports/4632.

NBS. (2005). The Nigeria Poverty Profile 2004 Report. National Bureau of Statistics (NBS), Abuja, Nigeria.

Swamy, G. and H. Biswanger. (1983): "Flexible consumer demand systems and linear estimation: food in India." America Journal of Agricultural Economics 65(4). 